\title{
SEED REARING OF RUDITAPES DECUSSATUS (BIVALVIA: MOLLUSCA) USING TWO CULTURE TECHNIQUES
}

\author{
Mahmoud Sami $^{1}$, Deyaaedin A Mohammad ${ }^{1}$, Alaa El-Din Sallam ${ }^{2}$, Saad Z Mohammed ${ }^{1}$ \\ ${ }^{1}$ Suez Canal University, Faculty of Science, Department of Marine Science \\ ${ }^{2}$ Suez Canal University, Faculty of Science, Zoology Department \\ [E-mail: Mahmoud_sami61@yahoo.com]
}

\begin{abstract}
The carpet shell clam, Ruditapes decussatus is one of the most popular and commercially important mollusks in Egypt. This study aimed to investigate the effect of density (50, 150 and 200 ind $/ \mathrm{m}^{2}$ ) and temperature $\left(21\right.$ and $24^{\circ} \mathrm{C}$ ) on growth performances and survival rates of Ruditapes decussatus seeds using two different techniques (racking cage and closed system). The growth performances were determined by measurement of all biometric measurements comprised shell length, height, width, total weight, soft body weight and dry weight before, through and at the end of the experiments. The best growth was recorded in density 150 ind $/ \mathrm{m}^{2}$ in the racking cage. Concerning temperature experiment, the highest growth performances were recorded at $21 \pm l^{\circ} \mathrm{C}$ compared with other higher temperature.
\end{abstract}

Keywords: Ruditapes decussatus; density; temperature; racking cage; closed system; growth.

\section{INTRODUCTION}

Aquaculture can be considered as the most effective method to solve the problem of the depletion of the natural clam stock. There are a number of techniques or systems that are used for rearing most clams and other bivalves such as: (1) Floating upwelling system (FLUPSY) which is a nursery system that promotes the growth of juveniles or seed clams. In this technique, water welling was used to force feed nutrient-rich water to the juveniles through an intensive, controlled nursery system (Jones et al., 1993). (2) Closed aquaculture systems (CASs), which represent the most common rearing method used in bivalve hatcheries (Helm and Bourne, 2004; Rico-Villa et al., 2006). (3) The flow through system (FTS) which is based on regular exchange of water for the reduction of bacteria as well as toxic matters which are gathered in the rearing water (New and Valenti, 2000). This method has been successfully used in the nursery culture of oysters, scallops, clams, mussels and in numerous fish hatcheries (Andersen et al., 2000; Ritar, 2001; Tieman and Goodwin, 2001; Otoshi et al., 2003; Sarkis et al., 2006; RicoVilla et al., 2008).

Growth performance and survival rates are considered as the main factors in aquaculture as they provide information to maximize yield per unit of time and space as well as to determine the required time to harvest clams commercially. The optimal seeding size, seeding season, optimal stocking density are significant factors that affect the growth performance of the cultured species (Dhraief $e t$ al., 2016).

Nutrition is crucial in bivalve growth and survival (Marshall et al., 2010). In traditional mollusc hatcheries, bivalves are fed live microalgae (Pernet et al., 2003). The principles for choosing a suitable algal diet for bivalve larvae (or seed) depends on the form, mobility, size, toxicity as well as the ability of the bivalve or seed to trap, consume, digest and engulf the algae. However, mass production of microalgae for molluscs rearing in hatcheries and nurseries is very costly since this practice calls for experienced labor and ardent facilities which sum up to $20-50 \%$ of the overall seed production costs (Borowitzka, 1999).

According to Krom et al. ( 1985) and Porter et al. (1987), to solve nutrition problems, the rearing of seed clam should be started in marine fish ponds where only $20-30 \%$ of the nitrogen and phosphorus added as food is utilized by the fish. This represents an inefficient utilization of nitrogen and capital investment. In addition, the excess metabolites produced by the fish enhance the development of rich phytoplankton blooms, which often reach dangerous levels for the fish as well as 
being a source of environmental pollution when the drainage water enters the sea. Edible, filterfeeding bivalves with high commercial value improve water quality, produce a high value by-product, and are an ideal solution to the problem of utilization of the excess phytoplankton ( Motzkin et al., 1982; Shpigel and Fridman, 1990).

The influence of food availability on bivalve growth depends on the environmental factor which consequently affects the physiological parameters that integrate the energy-balance equation (Bayne and Newel1, 1983). The ingestive and digestive capacity of these animals are the most important factors determining the energy available for growth. Therefore, the effect of food availability on growth is conditioned by the way in which this environmental variable acts on ingestion and absorption rates (Bayne et al., 1989).

Temperature is a very important factor limiting bivalve distribution, affecting their activity level and energy balance. Temperature tolerance can be modified by physiological processes, including feeding activity, metabolism and growth (Kinne, 1971; Hoffmann, 1983) and behavioral acclimation to the temperature regime of the animal's environment. The present study aims to evaluate the effect of different stocking density in racking technique on growth performance and survival rates of the clam Ruditapes decussatus seeds reared in private marine fish pond and under controlled temperature in closed laboratory system (closed- down welling techniques).

\section{MATERIALS AND METHODS}

Experiment 1: This experiment was used to determine the effect of density of seed per square meter in racking technique on growth rate.

\section{Preparation of racking cage}

The cage was deployed using iron stakes with $80 \mathrm{~cm}$ in length and a $3 \mathrm{~mm}$ mesh net attached to the stakes. The cage was divided to three racks and each rack was divided equally to three parts (as three replicates) and the surface area for each part was 50 X $50 \mathrm{~cm}$ (length and width, respectively). The distances between each rack were $20 \mathrm{~cm}$. The surface area for each rack equal 150 X $50 \mathrm{~cm}$ (length and width, respectively). All cage frames were covered with net to protect clam seed from predators (fish). These racks were named as upper, middle and lower racks. The densities of seed were 50 ind. $/ \mathrm{m}^{2}$ in upper rack, $150 / \mathrm{m}^{2}$ for middle rack and $200 \mathrm{ind} . / \mathrm{m}^{2}$ for lower rack.

\section{Experimental setup}

The experiment was performed for two months (from October 8th- December 3rd 2016) in a private fish farm located in AbuSultan, Ismailia, where water exchange occurs by tidal exchange and wind. The average depth of the pond was $1 \mathrm{~m}$, with a maximum depth of about $1.5 \mathrm{~m}$. Three replicates for each density were made. Specimens were purchased from clam collectors working at Lake Timsah in October 2016. Their shell lengths were measured by digital Vernier caliper with an accuracy of $0.01 \mathrm{~mm}$ and their weights were measured using Sartornus balance with an accuracy of $0.01 \mathrm{~g} .39$ seed clams with a mean length and weighted $18.03 \mathrm{~mm} \pm 1.14$ and 1.03 $\mathrm{g} \pm 0.13$, respectively, were stocked in the upper rack (13 individuals / $0.25 \mathrm{~m}^{2}$ ). 114 seed clams with a mean length and weight of $18.13 \mathrm{~mm}$ \pm 0.97 and $1.06 \mathrm{~g} \pm 0.16$, respectively, were stocked in the middle rack (38 individuals / $0.25 \mathrm{~m}^{2}$ ). 150 seed clams with a mean length of $18.35 \mathrm{~mm} \pm 0.85$ and $1.06 \mathrm{~g} \pm 0.13$, respectively, were stocked in the lower rack (50 individuals / $0.25 \mathrm{~m}^{2}$ ). Particular attention has been taken place to the cleanness of farming nets (cage nets) to ensure normal respiration and adequate alimentation of the clams.

\section{Water quality parameters}

The parameters (temperature, salinity and $\mathrm{pH}$ ) of water quality in the fish farm were monitored once a week between $1.00 \mathrm{pm}$ to $3.00 \mathrm{pm}$. Total suspended matter was estimated biweekly and chlorophyll- $a$ content once monthly. $\mathrm{pH}$ was measured by means of multimeter (Model AD1030, pH/mv). Temperature was measured with a mercury-inglass thermometer ( -10 to $100 \pm 0.5^{\circ} \mathrm{C}$ ). Salinity was measured using a refractometer (Model Atago S/ Mill salinity meter 100\%). Chlorophyll-a was measured using the spectrophotometric method (Strickland and Parsons1972). Five liters of seawater were filtered using what man filter paper for suspended matter estimation. It was then placed in an oven for 1 hour at $104{ }^{\circ} \mathrm{C}$. The weight of 
the filter paper was recorded before and after drying and total suspended matter (TSM) was calculated as the weight difference between the two recordings and expressed as $\mathrm{g} / \mathrm{l}$.

\section{Experiment 2}

This experiment was used to determine the effect of temperature on growth rate and survival rate of seed clams in closed downwelling technique.

\section{Preparation of experimental tanks}

Two square fiber glass tanks (large tanks) with dimensions of 60 X 60 X $30 \mathrm{~cm}$ (length X width $X$ height) and four plastic tanks (small tanks) with dimensions of $25 \times 20 \times 15 \mathrm{~cm}$ (length $\mathrm{X}$ width $\mathrm{X}$ height) were used in this experiment. The tanks were disinfected with formaldehyde (38\%), washed and then left to dry. The large tanks filled with 35 liters. Each two small tanks put up or placed above a large tank via wood panel. The small tanks filled with 51 from large tank by means of a peristaltic pump (in closed circuit) with flow rate $1 \mathrm{~L} / \mathrm{min}$ (Fig. 1). All tanks aerated using a blower (Model BOYU ACQ-009 Air compressor electromagnetic, China) to reduce food setting or sedimentation. Water salinity was maintained constant at $25 \%$. The tape water added to the large tank to replace or compensate the raise of salinity due to evaporation. Water temperature in two large tanks were kept constant at $21 \pm 1{ }^{\circ} \mathrm{C}$ and $24{ }^{\circ} \mathrm{C}$ by means of an aquarium heater (Model MINJIANG HK-300, China).

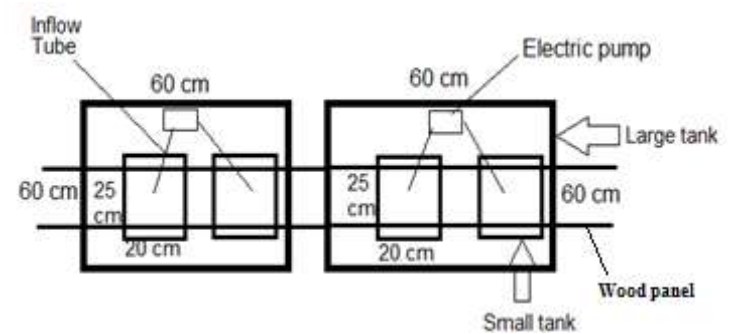

Fig. 1: Sketch showing the structure of closed rearing system.

\section{Experimental setup}

The experiment was performed in the Mariculture laboratory, at the Department of Marine Science, Suez Canal University, Ismailia, for four weeks from November $30^{\text {th }}-$ December $28^{\text {th }} 2016$. Two replicates for each tested temperature were made; the tested temperature were $21 \pm 1{ }^{\circ} \mathrm{C}$ and $24{ }^{\circ} \mathrm{C}$. Eight specimens were stocked per small tank with a mean length and weight of $16.709 \mathrm{~mm}$ and $0.840 \mathrm{~g}$, respectively. Specimens in the small tanks placed above the large tank (with water temperature $21 \pm 1{ }^{\circ} \mathrm{C}$ ). Other specimens with a mean length and weight of $16.579 \mathrm{~mm}$ and $0.825 \mathrm{~g}$, respectively, were stocked in the second small tanks which subsequently placed above other large tank with water temperature $24{ }^{\circ} \mathrm{C}$. The daily feeding rate was $4 \%$ of seed dry weight. The algal food (Tetraselmis sucica) was suspended in large tanks with strong aeration, to keep the food in suspension. The excreted feces from seed removed from small tanks using siphonation each three day to minimize nitrogen wastes.

\section{Algal culture}

Tetraselmis suecica were cultured in $5 \mathrm{~L}$ and $20 \mathrm{~L}$ glass and plastic vessels in Mariculture laboratory at temperature $21^{\circ} \mathrm{C} \pm 1$ with continuous illumination by vertical "daylight" fluorescent lamps. Salinity was fixed at 32\%. The culture medium described by Walne (1966) was used. Culture medium was added constantly ( $1 \mathrm{~mL}$ per L of algal culture). Continuous aeration was provided to prevent the algae from settling. Microalgae were harvested during the initial stationary phase of growth. Before being used as food, algal cells were counted with counter cell to determine the amount of algae which used in daily feeding.

\section{Seed sampling}

Samples were taken at four different times (day $0-\mathrm{T} 0$; day $14-\mathrm{T} 1$; day $28-\mathrm{T} 2$; day 42- T3 and day $56-\mathrm{T} 4$ ) with an interval of about two weeks between each sampling) for the first experiment. In the second experiment, the measurements were performed at the beginning (day $0-\mathrm{T} 0$ ) and the end (day $28-$ T1). In each interval, shell length and total weight were measured for each replicate (in two experiments) while the height, width, dry weight and soft body weight were measured in the beginning and the end of the first experiment. The total weight, dry weight and soft body weight measured by means of an electronic balance, with an accuracy of $0.01 \mathrm{~g}$. Before weighing the seed, they were dried on absorbent paper for $10 \mathrm{~min}$, to remove surface water. Dry weight was determined by drying the seed at $100^{\circ} \mathrm{C}$ for $24 \mathrm{~h}$. 


\section{Growth performance analysis}

The growth of all individuals was estimated based on six biometric parameters: length (L), height $(\mathrm{H})$, width $(\mathrm{W})$, live weight (LW), dry weight (DW) and soft body weight (SW). To evaluate the individual's total growth rate, the instantaneous (specific) growth rate $(\mathrm{K})$ was calculated using the following equation (Malouf and Bricelj, 1989):

$$
\mathrm{K}=\left(\ln \mathrm{W}_{2}-\ln \mathrm{W}_{1}\right) * 100 /\left(\mathrm{t}_{2}-\mathrm{t}_{1}\right)
$$

Where $W_{2}$ and $W_{1}$ are the values of the different variables $\mathrm{H}, \mathrm{W}, \mathrm{SW}, \mathrm{DW}, \mathrm{LW}$ and L. at the end and beginning of each experiment, respectively and " $t$ " is the number of days.

Survival (\%) was estimated as $\left(\mathrm{N}_{\mathrm{t}} / \mathrm{N}_{0}\right) \mathrm{x}$ 100 , where $N_{t}$ is the number of live clams removed from the culture area after $t$ and $\mathrm{N}_{0}$ is the number of clams at the beginning of the experiment.

The total weight gain (TWG), length gain (LG), height gain (HG), width gain (WG), soft weight gain (SWG) and dry weight gain (DWG) were calculated according to the following equations, respectively

$$
\begin{array}{lr}
\text { TWG }=\text { FBW }- \text { IBW [2] } & \text { LG }=\text { FL }- \text { IL [3] } \\
\text { HG }=\text { FH }- \text { IH } & {[4]} \\
\text { WG }=\text { FW }- \text { IW } & {[5]} \\
\text { SWG }=\text { FSW }- \text { ISW } & {[6]} \\
\text { DWG }=\text { FDW }- \text { IDW } & {[7]}
\end{array}
$$

Where $\mathrm{F}$ and I represent the final and initial of variables, respectively.

\section{Statistical analysis}

Statistical analysis was performed using SPSS (Version 22). Differences in specific growth rate and growth gain of shell length, height, width, total weight, dry weight, soft weight and survival rate among different densities were determined using a one-way ANOVA in the two experiments. If significant differences were present, LSD post hoc test was employed to check for differences between means. Significance levels for all analysis were set at $\mathrm{P}<0.05$.

\section{RESULTS}

\section{Experiment 1}

Water quality parameters

Temperature, salinity and $\mathrm{pH}$

Water temperature ranged between $17{ }^{\circ} \mathrm{C}$ in December $3^{\text {rd }} 2016$ and $30{ }^{\circ} \mathrm{C}$ in October $8^{\text {th }}$
2016, while salinity ranged between $25 \%$ in October $8^{\text {th }} 2016$ and $28 \%$ in October $22^{\text {th }}$ and December $3^{\text {rd }} 2016$ (Fig.2). The maximum value of $\mathrm{pH}$ (8.2) was recorded in December $3^{\text {rd }}$ 2016, while the minimum (7.7) was in October $8^{\text {th }} 2016$ (Fig. 2).

\section{Chlorophyll-a and total suspended matter (TSM)}

Chlorophyll-a ranged between $6.7 \mu \mathrm{g} / \mathrm{l}$ in December 2016 and $7.5 \mu \mathrm{g} / \mathrm{l}$ in October 2016 (Fig. 3). The lowest value of TSM was $0.09 \mathrm{~g} / \mathrm{l}$ in December 2016 and the highest was $0.25 \mathrm{~g} / \mathrm{l}$ in October 2016 (Fig. 3).

\section{Growth performance analysis}

\section{a- Specific growth rate (SGR) and total growth gain}

Differences in specific growth rate (SGR) and growth gain (GG) of shell length (SL), height $(\mathrm{H})$, width (W), total weight (TW) soft body weight (SBW) and dry weight (DW) with different densities are shown in Figs. (4 - 9). The highest values of SGR and GG of SL, H, $\mathrm{W}, \mathrm{SBW}$ and DW were recorded in density 150 ind $/ \mathrm{m}^{2}$ (0.2607, 0.3480, 0.4889, 1.346 and 0.9993 , respectively). However, the highest values of SGR and GG of TW were recorded in density $50 \mathrm{ind} / \mathrm{m}^{2}$. The lowest values of SGR and GG of all biometric measurements were recorded in density $200 \mathrm{ind} / \mathrm{m}^{2}$. The differences in total increment of all biometric measurements were not significant except for those of length and total weight $(P<0.05)$. However, the differences between the total increment of length and total weight at density $50 \mathrm{ind} / \mathrm{m}^{2}$ and $150 \mathrm{ind} / \mathrm{m}^{2}$ were not significant but these densities were significant with density $200 \mathrm{ind} / \mathrm{m}^{2}$. The differences in SGR of all biometric measurements were not significant except for length $(P<0.05)$. However, the differences in SGR of length at density 50 $\mathrm{ind} / \mathrm{m}^{2}$ and $150 \mathrm{ind} / \mathrm{m}^{2}$ were not significant but these densities were significant with density $200 \mathrm{ind} / \mathrm{m}^{2}$. Although the differences between SGR of total weight were not significant, the differences in SGR of total weight at density 50 $\mathrm{ind} / \mathrm{m}^{2}$ were significant with density 200 ind. $/ \mathrm{m}^{2}$. 


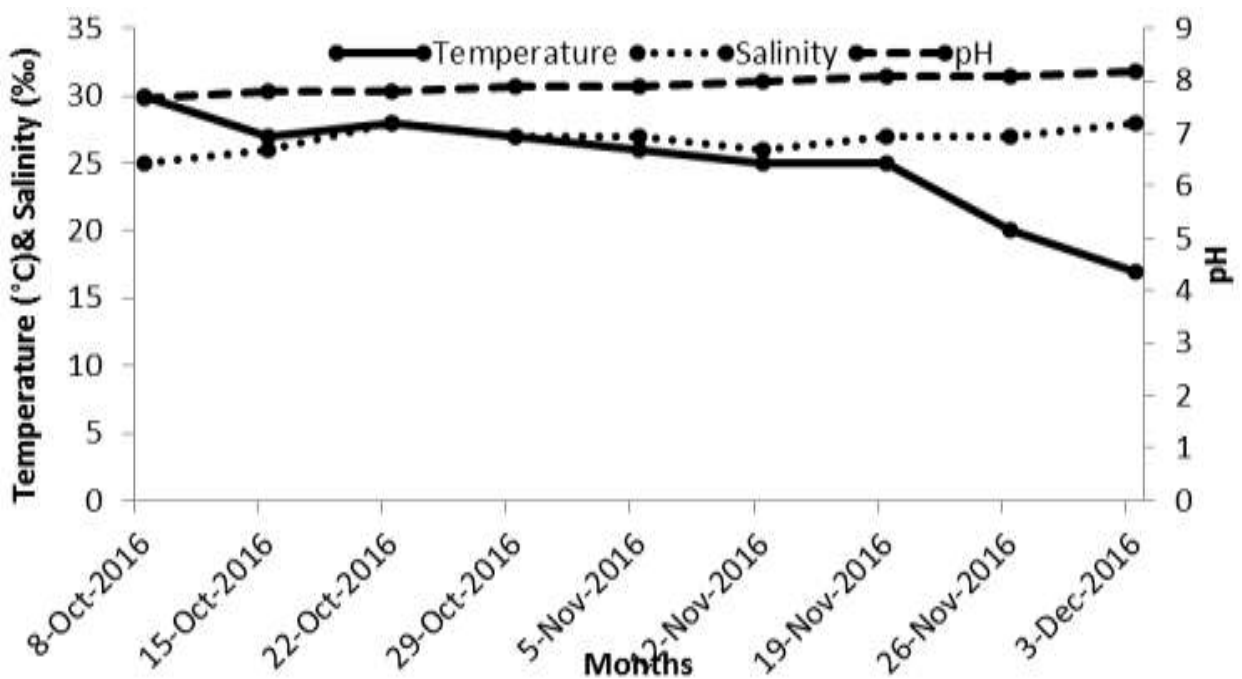

Fig. 2: Values of temperature, salinity and $\mathrm{pH}$ recorded in the fish pond during the experimental period.

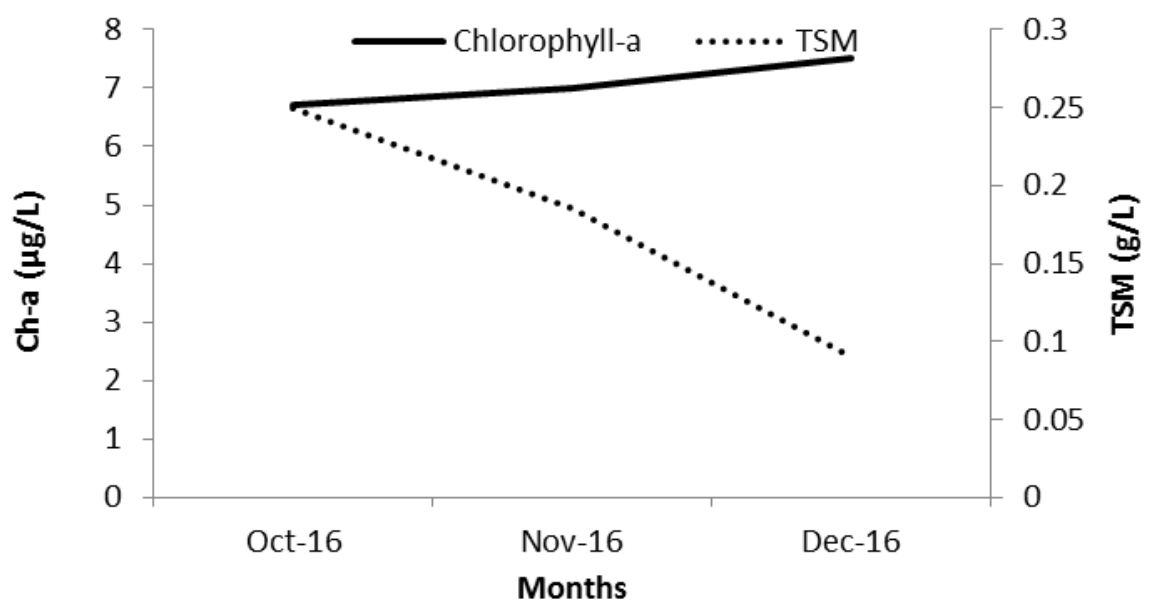

Fig. 3: Values of Chlorophyll- $a(\mathrm{Ch}-\mathrm{a})$ and TSM recorded in the fish pond during the experimental period.

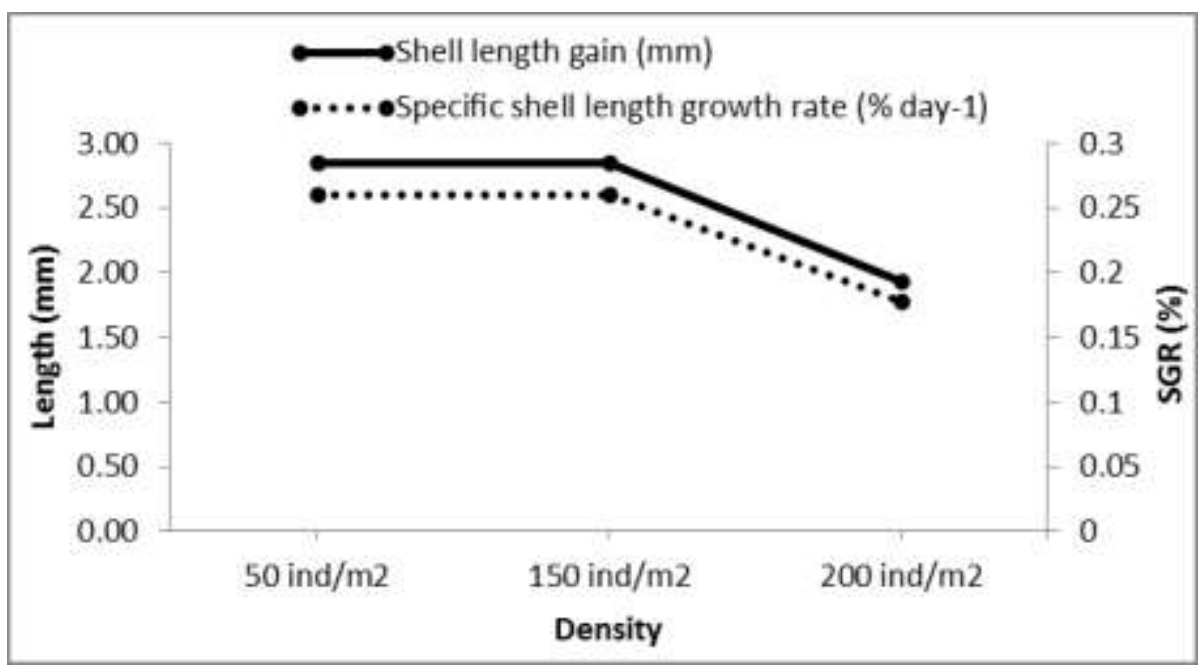

Fig. 4: Specific growth rate (SGR) and shell length gain in the different densities. 


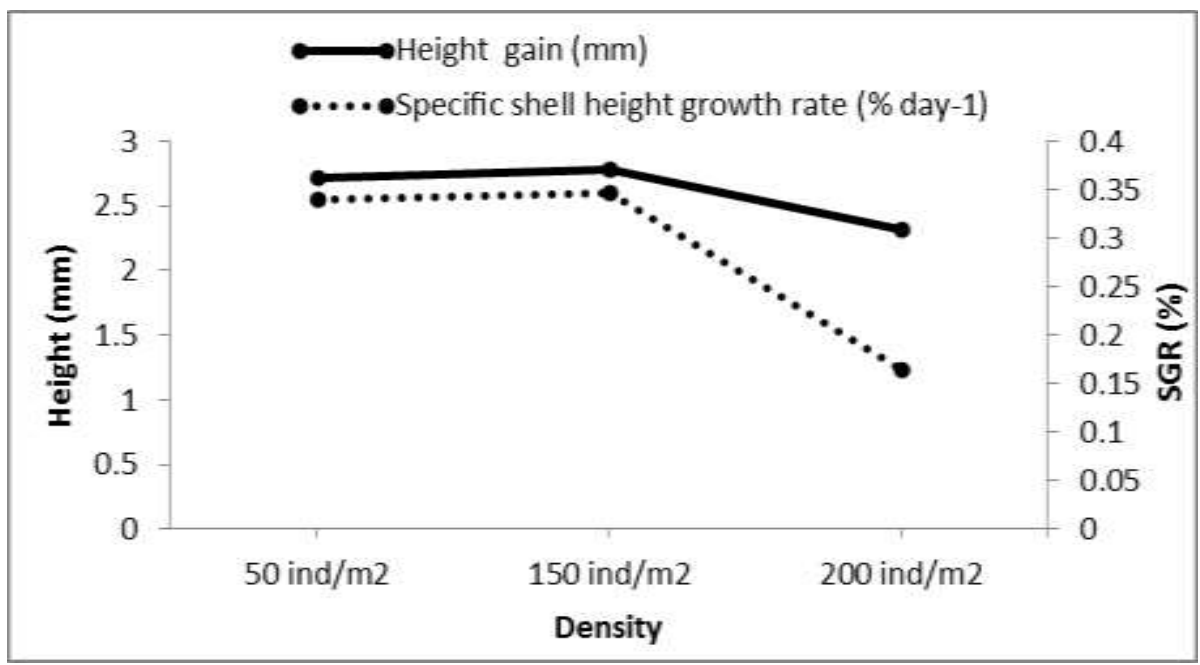

Fig. 5: Specific growth rate (SGR) and shell height gain in the different densities.

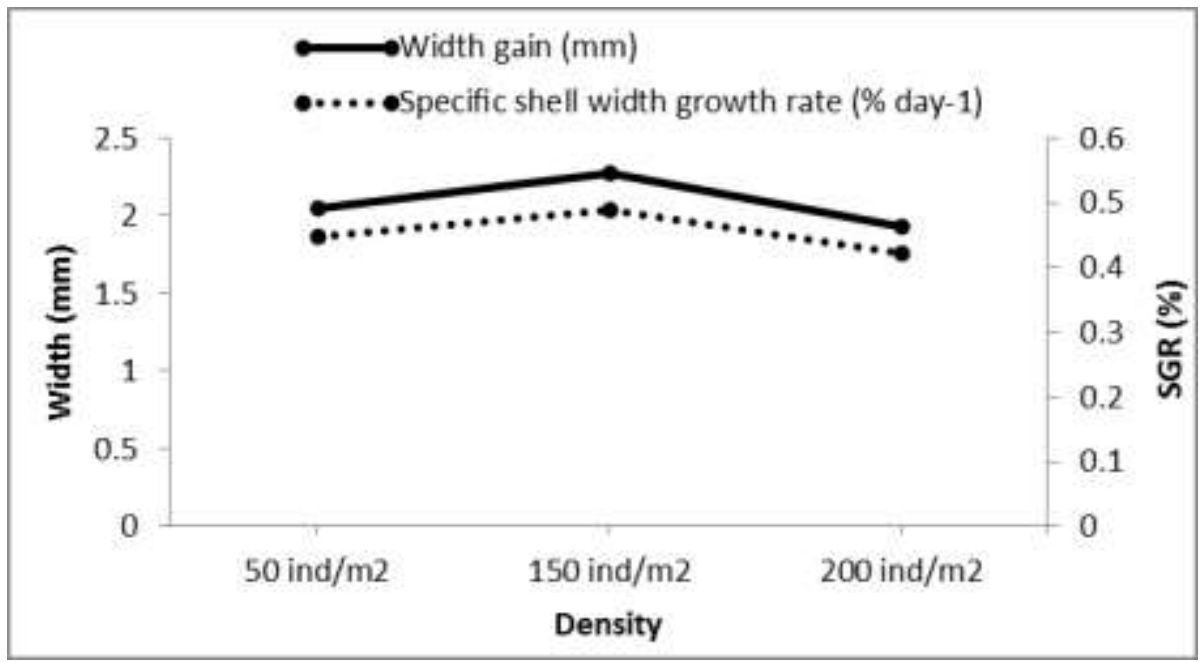

Fig. 6: Specific growth rate (SGR) and shell width gain in the different densities.

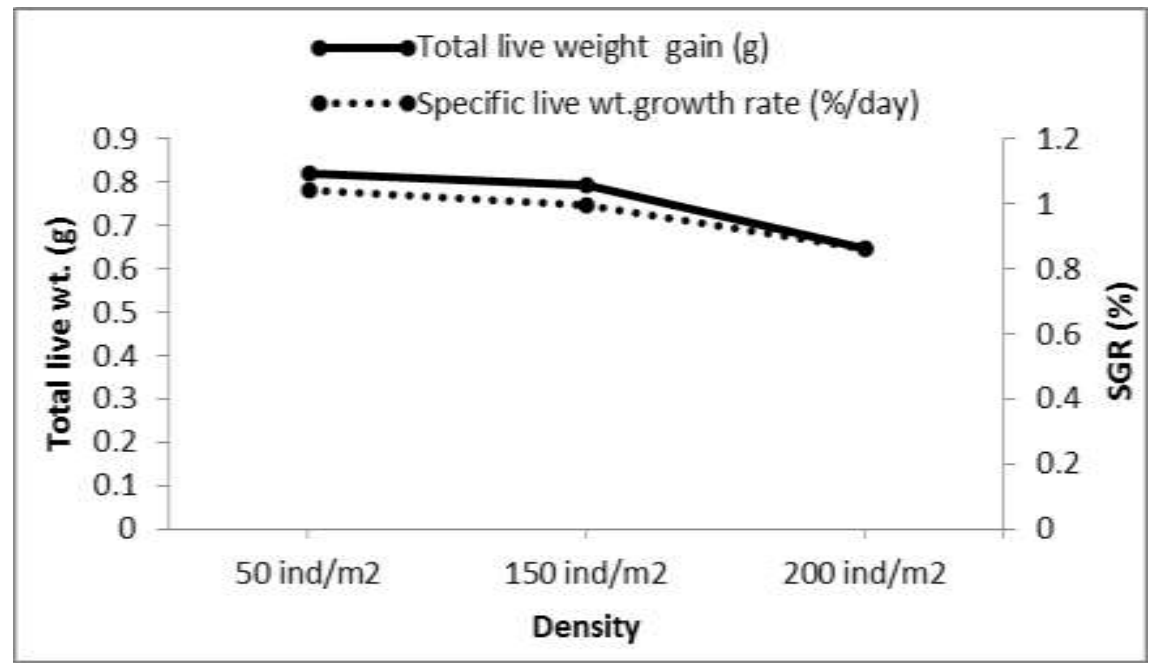

Fig. 7: Specific growth rate (SGR) and live weight gain in the different densities. 


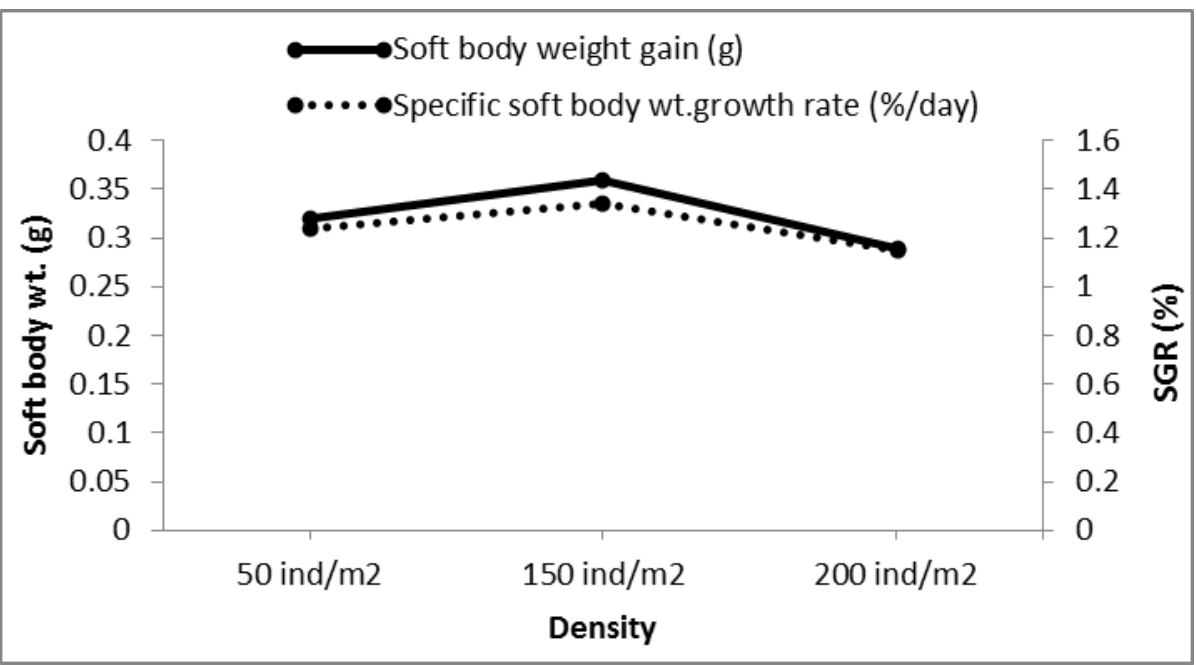

Fig. 8: Specific growth rate (SGR) and soft body weight gain in the different densities.

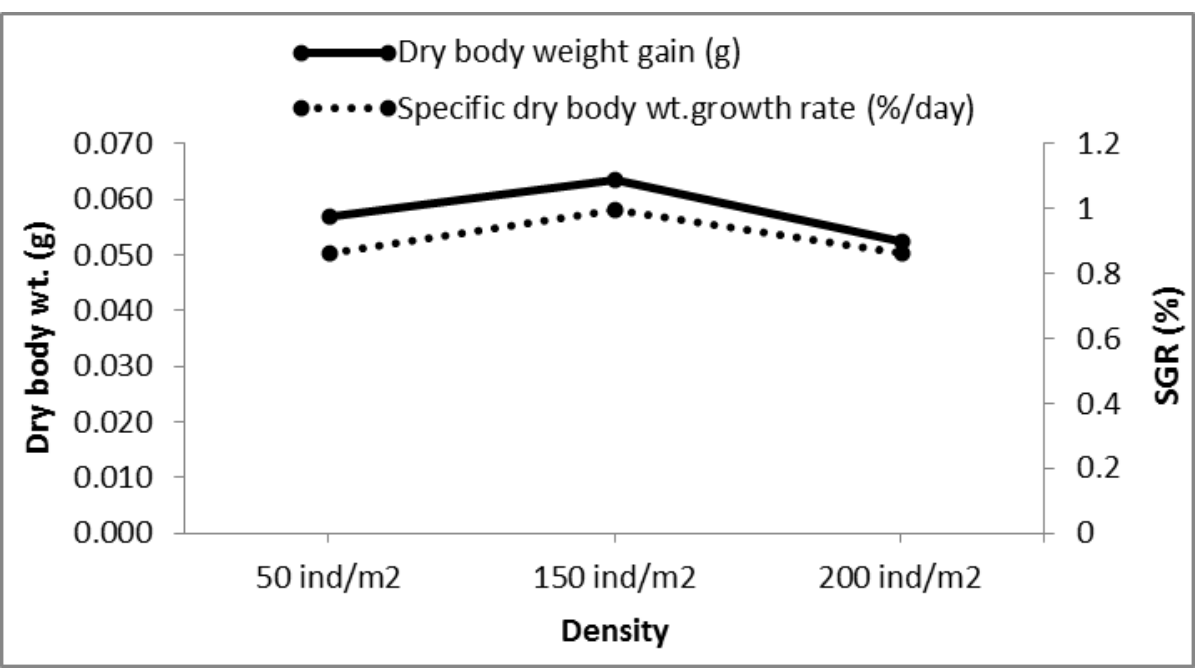

Fig. 9: Specific growth rate (SGR) and dry weight gain in the different densities.

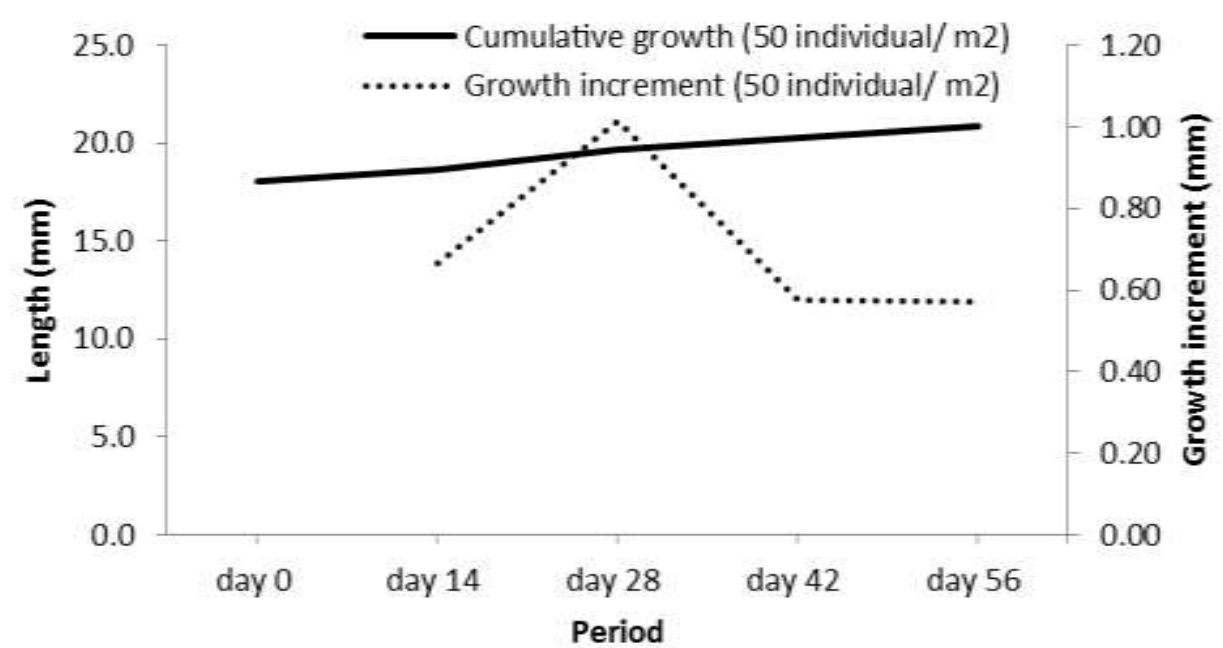

Fig. 10: The cumulative growth and growth increment of shell length for density $\left(50 \mathrm{ind} / \mathrm{m}^{2}\right)$ during experimental time intervals. 


\section{b- Cumulative growth and growth increment}

The cumulative growth and growth increment with interval experimental periods (T0 - T4) for shell length and total weight are illustrated in Figs. (10 -15) for different densities. The figures clarify the following:

- At the density $50 \mathrm{ind} / \mathrm{m}^{2}$, the initial length and weight were $18.03 \mathrm{~mm}$ and $1.03 \mathrm{~g}$, respectively, and reached $20.86 \mathrm{~mm}$ and $1.85 \mathrm{~g}$, respectively, at the end of experiment (56 days). The highest and the lowest length increment were recorded at day 28 and day 56, respectively. The highest and the lowest weight growth increment were recorded at day 56, day 28, respectively (Figs. $10 \& 13$ ).

- At the density $150 \mathrm{ind} / \mathrm{m}^{2}$, the initial length and weight were $18.13 \mathrm{~mm}$ and $1.06 \mathrm{~g}$, respectively, and reached $20.98 \mathrm{~mm}$ and $1.85 \mathrm{~g}$, respectively, at the end of experiment. The

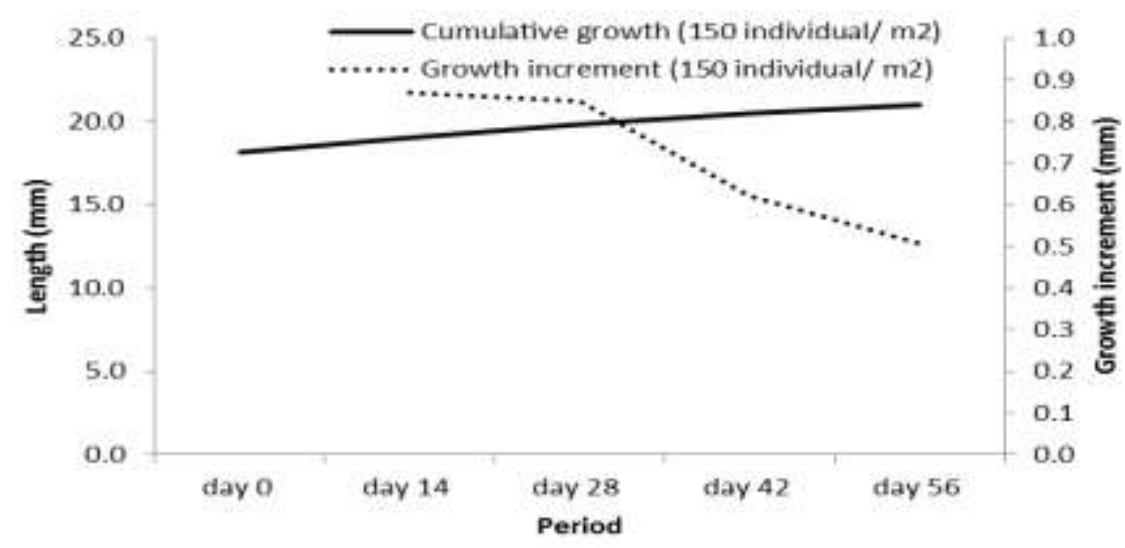

Fig. 11: The cumulative growth and growth increment of shell length for density $\left(150 \mathrm{ind} / \mathrm{m}^{2}\right)$ during experimental time intervals.

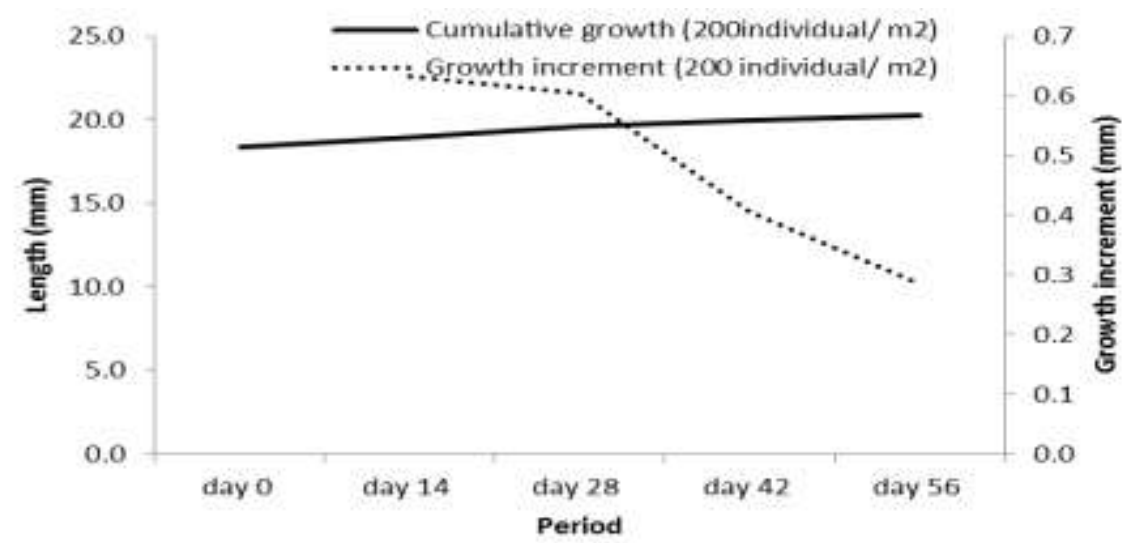

Fig. 12: The cumulative growth and growth increment of shell length for density $\left(200 \mathrm{ind} / \mathrm{m}^{2}\right)$ during experimental time intervals.

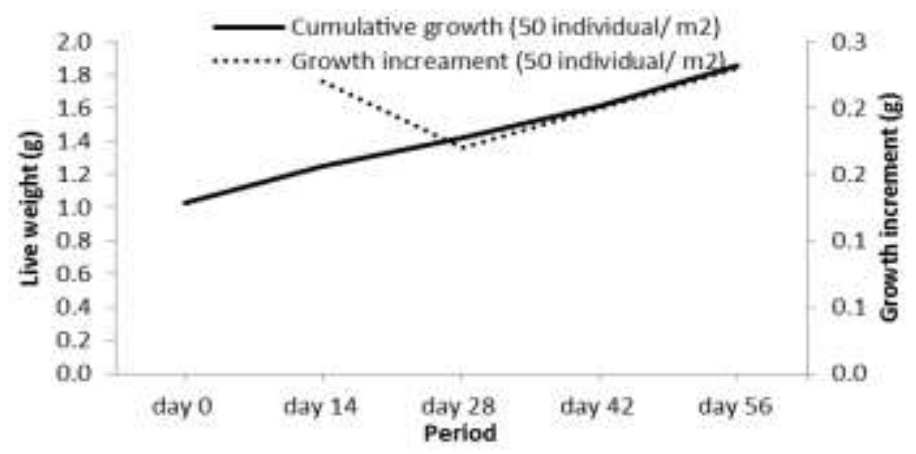

Fig. 13: The cumulative growth and growth increment of total weight for density $\left(50 \mathrm{ind} / \mathrm{m}^{2}\right)$ during experimental time intervals. 
highest and the lowest length increment were recorded at day 14 and day 56, respectively. The highest and the lowest weight growth increment were recorded at day 14 , and day 56, respectively (Figs. 11\&14).

- At the density $200 \mathrm{ind} / \mathrm{m}^{2}$, the initial length and weight were $18.35 \mathrm{~mm}$ and $1.06 \mathrm{~g}$, respectively, and reached to $20.28 \mathrm{~mm}$ and 1.72 $\mathrm{g}$, respectively, at the end of experiment. The highest length and weight growth increment were recorded at day 14 , but the lowest were recorded at day 56 for length and weight (Figs. $12 \& 15)$

Fig. 15: The cumulative growth and growth increment of shell length for density (200 $\mathrm{ind} / \mathrm{m}^{2}$ ) during experimental time intervals.

The survival rates of the three densities ranged from 85.33 to $87.18 \%$ with no significant differences among the experimental densities $(\mathrm{P}>0.05)$.

\section{Experiment 2}

\section{Growth performance analysis}

Mean values of specific growth rate (SGR) and growth gain (GG) of shell length (SL), total weight (TW) soft body weight (SBW) and dry weight (DW) recorded under different temperatures are shown in Figs. (17- 20), respectively. The highest values of SGR and GG of the four biometric measurements were recorded at temperature $\left(21 \pm 1{ }^{\circ} \mathrm{C}\right)$. The differences in growth gain and specific growth rate in all the biometric measurements were not significant with different temperature. The means initial and final values of the four biometric measurements in the two different temperatures were represented in Table 1.
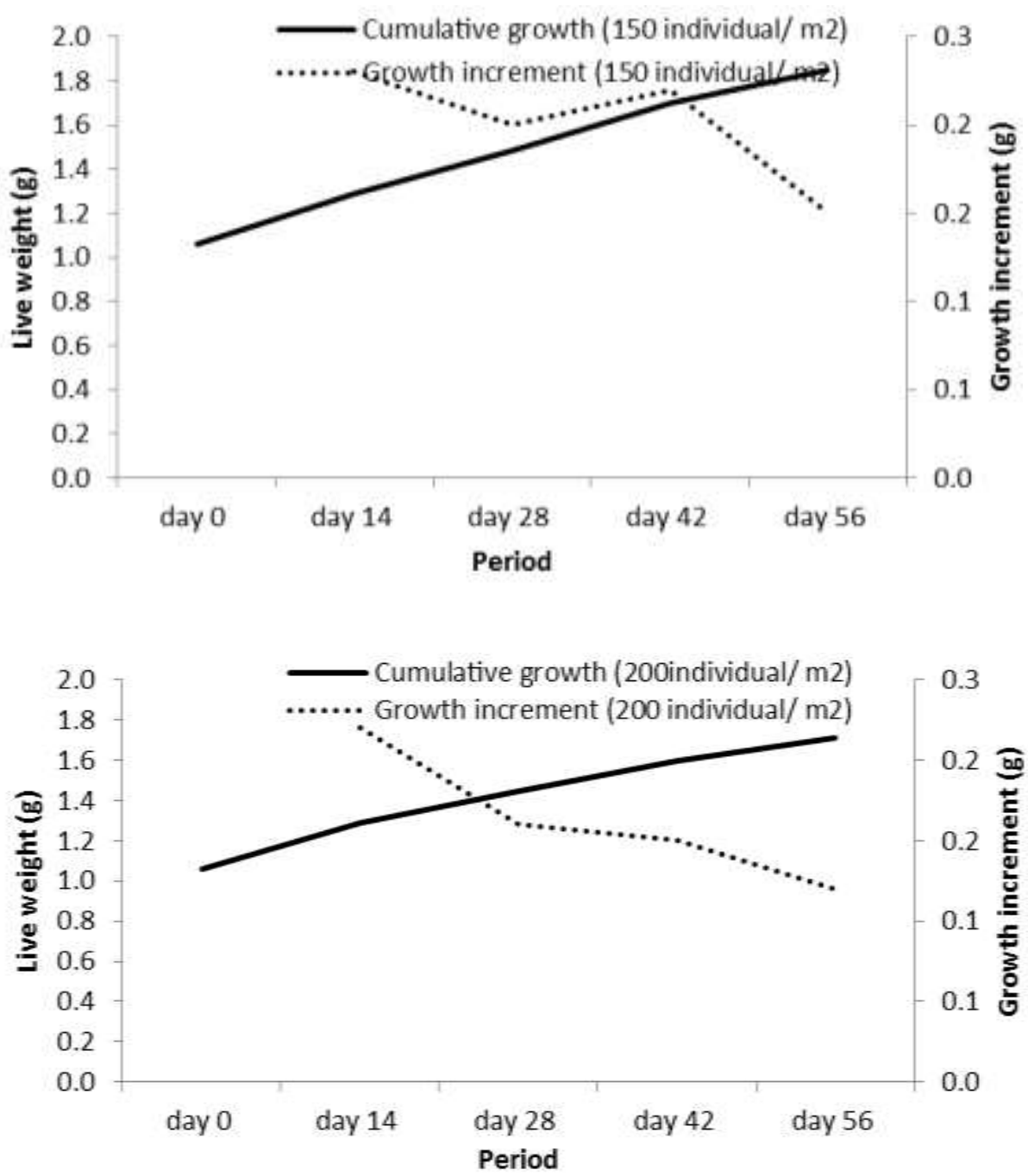

Fig. 15: The cumulative growth and growth increment of shell length for density $\left(200 \mathrm{ind} / \mathrm{m}^{2}\right)$ during experimental time intervals. 


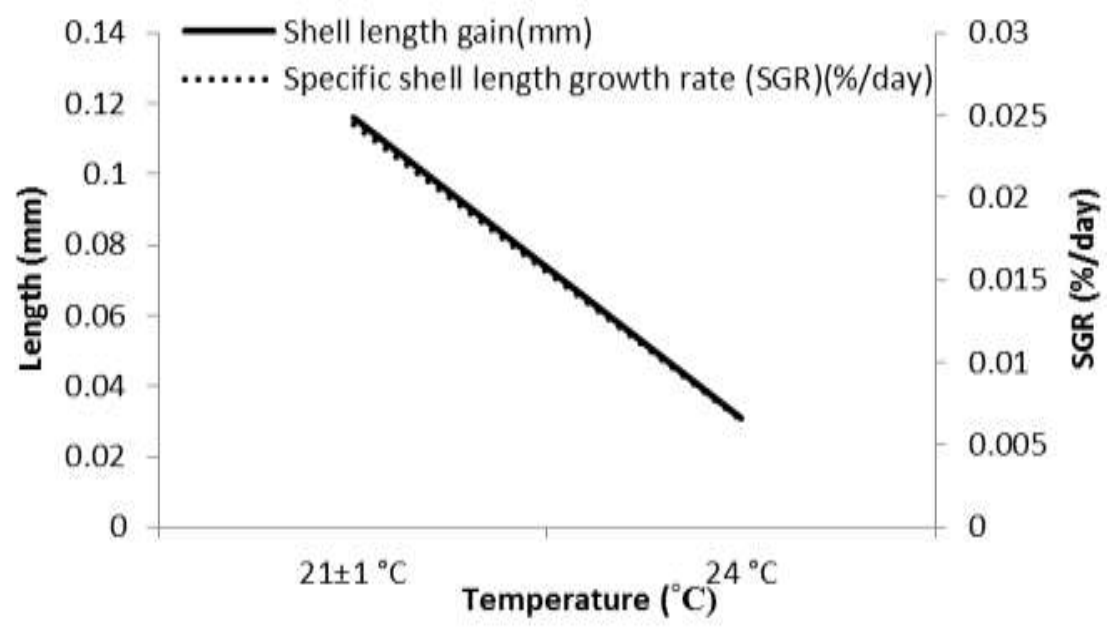

Fig. 16: Specific growth rate (SGR) and shell length gain in the two temperatures.

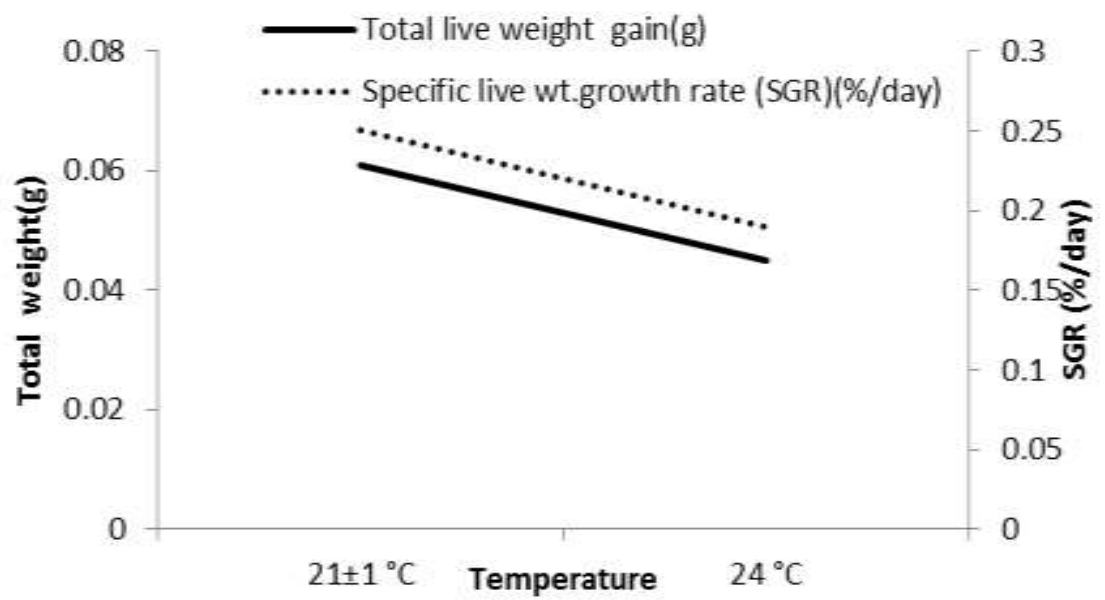

Fig. 17: Specific growth rate (SGR) and total weight gain in the two temperatures.

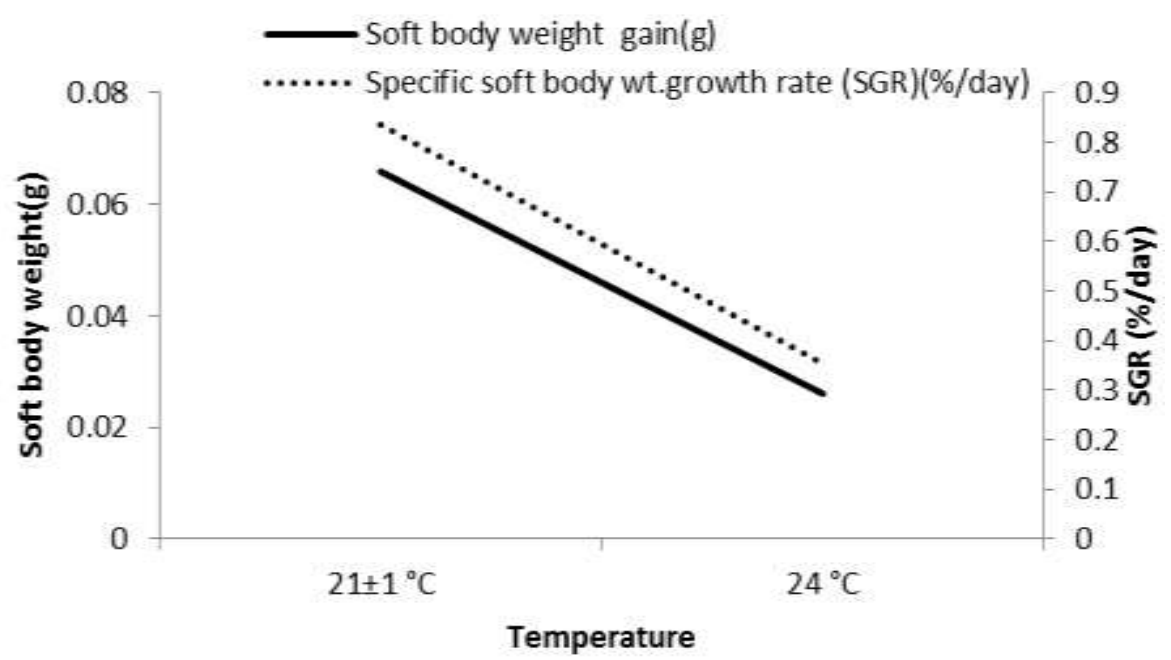

Fig. 18: Specific growth rate (SGR) and soft body weight gain in the two temperatures. 


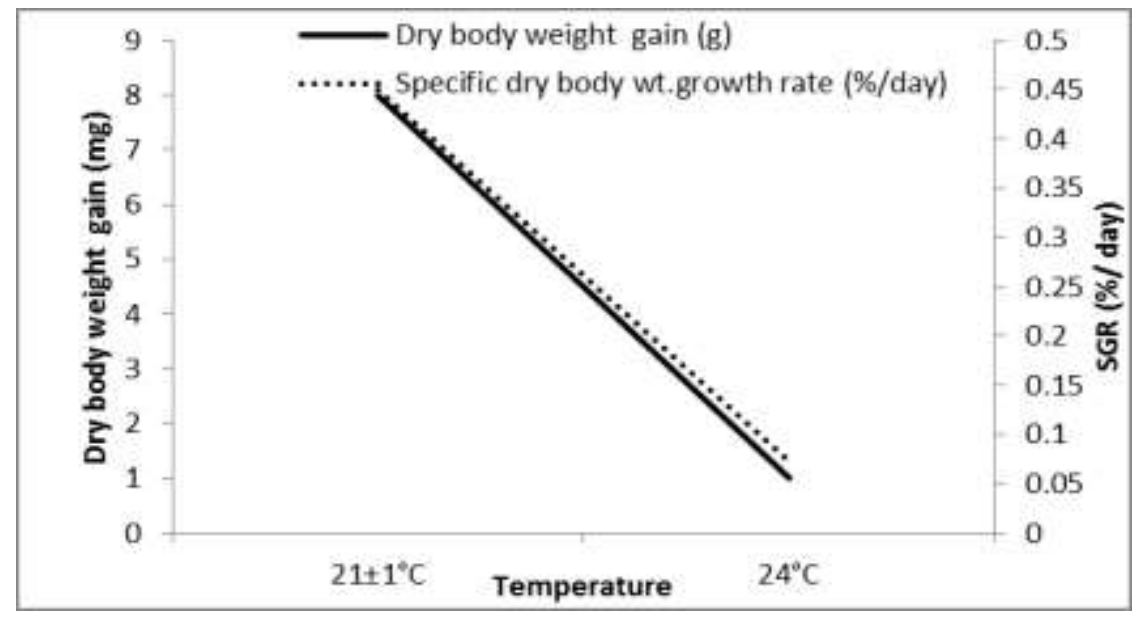

Fig. 19: Specific growth rate (SGR) and dry weight gain in the two temperatures.

Table 1: Means of initial and final values of shell length (SL), total weight (TW) soft body weight (SBW) and dry weight (DW) in the two different temperatures.

\begin{tabular}{|l|c|c|}
\hline \multicolumn{1}{|c|}{ Temperature } & $\mathbf{2 1}^{\mathbf{1}} \mathbf{1}^{\mathbf{}} \mathbf{C}$ & $\mathbf{2 4}^{{ }^{\circ} \mathbf{C}}$ \\
\hline Mean Initial length & 16.709 & 16.579 \\
\hline Mean Final length & 16.824 & 16.609 \\
\hline Initial body weight (IBW) & 0.840 & 0.825 \\
\hline Final body weight (FBW) & 0.901 & 0.870 \\
\hline Mean Initial Soft Body Wt. & 0.25 & 0.25 \\
\hline Mean Final Soft Body Wt. & 0.316 & 0.276 \\
\hline Mean Initial Dry Soft Body Wt. & 0.049 & 0.049 \\
\hline Mean Final Dry Soft Body Wt. & 0.057 & 0.050 \\
\hline
\end{tabular}

Survival rates at temperatures $21 \pm 1{ }^{\circ} \mathrm{C}$ and $24{ }^{\circ} \mathrm{C}$ were $93.75 \%$ and $100 \%$, respectively, by the end of the study. Although survival rate was higher at temperature $\left(24{ }^{\circ} \mathrm{C}\right)$ compared to other temperature, these differences were not statistically significant.

\section{DISCUSSION}

There are many factors that affect the growth of bivalves such as growing area, seasons of the year, temperature, quantity and quality of food as well as dissolved oxygen (Goulletquer et al., 1989, 1999; Baud and Bacher 1990; Chool-Shin and Shin, 1999; Sobral and Widdows, 2000). While many of these factors are dependent on each other, some of them are dominant; indeed food availability and temperature are the factors that have the major influence on growth (Eversole et al., 1986; Robert et al., 1993; Paterson and Nell,
1998). Other factors, such as salinity and oxygen, can affect the growth but do not appear to have a notable effect on the present results, since they were very stable and adequate for the clam growth.

\section{Effect of density on growth performance and survival rate}

In fish farm, (Abu-Sultan City), shell length (SL), shell height (SH), shell width (SW), total live weight (TW), soft body weight (SW) and dry body weight (DW) increments of $T$. decussatus were recorded. The results of growth increment (GI) of all biometric measurements shell length (SL), shell height (SH), shell width (SW), total live weight (TW), dry body weight (DW) and soft body weight (SW)) showed no significant differences among different densities in length and total weight. 
According to Dhraief et al. (2016), the density was considered the main factor that affect growth performance and survival rate of $R$. decussatus seed. However, their results clarify that the growth performance recorded in density 200 and $300 \mathrm{ind} / \mathrm{m}^{2}$ were higher than other density $\left(400\right.$ and $\left.500 \mathrm{ind} / \mathrm{m}^{2}\right)$. In the present study, the density 50 and $150 \mathrm{ind} / \mathrm{m}^{2}$ recorded higher growth performance and survival rate than the other density (200 ind $/ \mathrm{m}^{2}$ ). The low results of density of 200 ind $/ \mathrm{m}^{2}$ were confirmed by Saint-Flex et al., (1984) where they showed that the growth of clam was higher for rearing densities of 50 and $100 \mathrm{ind} / \mathrm{m}^{2}$ than for densities of 200,300 and $400 \mathrm{ind} / \mathrm{m}^{2}$.

Albentosa et al. (1997) recorded influences of quantity and food on growth performance of $R$. decussatus seed. Their results showed that the optimum feeding rate was $2 \%$ of dry or organic weight of seed in addition to that the live food is considered the most effective food. These results interpreted the good growth in the present study where there was high diversity of phytoplankton in fish farm.

Matias (2013) recorded the growth performance at the two different seeding sites in Formosa lagoon (Portugal) under different water quality parameters and constant density (300 ind $/ \mathrm{m}^{2}$ ). In general, their results were different with the present study. He recorded that growth increment in the two sites ranged from $8 \mathrm{~mm}$ to $10 \mathrm{~mm}$ per year. In the present study, the growth increment ranged from 1.93 to $2.85 \mathrm{~mm}$ at 56 days. The different results among two study can be attributed to the different stocking density, water quality (mainly temperature and chlorophyll-a), seeding size and different techniques.

Chessa et al. (2013) recorded different growth performance under different seasons (spring and autumn) and different techniques (natural rearing and floating upwelling system) for seeds of $R$. decussatus. The higher growth performance was recorded in spring and autumn seasons for floating upwelling system (10 $\mathrm{mm}$ in 101 day and $8 \mathrm{~mm}$ in 70 day, respectively) than the natural rearing. In the present study, the overall growth performance in all densities ranged from $1.93 \mathrm{~mm}$ to 2.85 $\mathrm{mm}$ in 58 day was smaller when compared to Chessa (2013) results.
Serder et al. (2007) recorded different growth performances under different culture methods and the preference of the hard plastic nets method $\left(7.63 \mathrm{~mm}\right.$ year $\left.^{-1}\right)$. In the present study, racking cage performed good growth in density 50 and $150 \mathrm{ind} / \mathrm{m}^{2}(2.83$ and $2.85 \mathrm{~mm}$ in 56 days, respectively) while low growth at density $200 \mathrm{ind} / \mathrm{m}^{2}$ (1.93 $\mathrm{mm}$ in 56 days). The overall growth performance in the present study was high than Serder et al. (2007) and Dhraief et al. (2016) (7-13 $\mathrm{mm}$ in 31 months) and Yamamoto and Iwata (1956) $(34.4 \mathrm{~mm}$ in 3 years), Shpigel and Fridman (1990), Breber (1985) (5 mm in 8 months), Matias (2013) (8$\left.10 \mathrm{~mm} \mathrm{year}^{-1}\right)$ and Lake (1992) (6-10 mm year ${ }^{-1}$ ) results. Rearing cages used in the present study seemed to be a suitable and good method for rearing clam seeds. It increases the surface area and performed a good growth conditions. The other techniques used by Serder et al. (2007) and Dhraief et al. (2016) depended mainly on the bottom culture (hard plastic net, box, polyamide net and fenced ground) without exploitation of water column. The previlage of the present method is the more exploitation of water column by increasing the surface area, yield and stocking density.

The specific growth rate (SGR) ranged from $0.002-0.003 \mathrm{day}^{-1}$ for shell length and 0.0086 - 0.01 day $^{-1}$ for total weight at different densities. These results were greater than Matias (2013) results where SGR of shell length were 0.0015 and 0.0016 through October and November 2008, respectively. The high SGR in the present study can be attributed to high food availability in Abu-Sultan fish pond and the suitable of water parameters (temperature, salinity and water flow,.....etc) and seeding size as well as stocking density.

The other critical factor controlling the rearing cycle is mortality rate, which can be either affected by water quality parameters (Gribben et al., 2002), type of substrate (Cigarria and Fernández, 1998), culture technique (Breber, 1985), planting season (Anderson et al., 1982), seed size (Spencer et al., 1991), predation (Toba et al., 1992) and presence of pathogens (Breber, 1985). The results of survival rates in different densities ranged from 85.33 to $87.18 \%$ through 8 weeks. The rate of mortality in this experiment were lower than recorded by Dhraief et al. (2016) 
which ranged from 44.67 to $48.33 \%$ through 31 months) and Serder et al. (2007) (ranged from 32 to $62 \%$ through 12 months). The mortality rate decreased through this experiment as the predation prevented via covering nets. The recorded mortality may be as result of appearance of fouling over the nets which can decline the penetration of water and water flow around clams.

Serder (2007) recorded the influence of different rearing techniques on survival rate of $R$. decussatus seed. The survival rate was high in the hard plastic net method (64\%) than other method as box and fenced (42\%) and polyamide $(32 \%)$. The cause of high mortality in box and fenced ground and polyamide methods were the clogging of openings nets and decline of flow rate of water. This interpretation agrees with reasons of mortality in the present study.

\section{Effect of temperature on growth performance and survival rate}

The growth rate of seeds in both trials was generally small but with preference of those recorded at $21{ }^{\circ} \mathrm{C}$ is compared to those at $24{ }^{\circ} \mathrm{C}$. The differences among trials were not significant. The growth increment (GI) of shell length and total weight were $0.116 \mathrm{~mm}$ and $0.061 \mathrm{~g}$ at temperature $21{ }^{\circ} \mathrm{C}$. According to Laing et al. (1987), the greatest growth-rate coefficients for $R$. decussatus juveniles occurred at $12-20^{\circ} \mathrm{C}$. These results interpreted the small growth in all trials especially at $24{ }^{\circ} \mathrm{C}$ in the present study. Albentosa et al. (1999) recorded good growth performance of $R$. decussatus that feed on $2 \%$ of dry weights of seed with Isochrysis galbana at temperature 21 $\pm 1{ }^{\circ} \mathrm{C}$. The length and total weight increments were $2.99 \mathrm{~mm}$ and $0.021 \mathrm{~g}$ through 6 weeks, respectively.

Albentosa et al. (1997) recorded growth performance of $R$. decussatus under different freeze-dried phytoplanktonic species (Isochrysis galbana, Tetraselmis suecica and Phaeodactylum tricornutum) at temperature 18 ${ }^{\circ} \mathrm{C}$. The total weight increment which ranged from 0.02 to $0.127 \mathrm{~g}$ which differ than the results in the present study where total weight increment ranged from $0.045 \mathrm{~g}$ to $0.0 .061 \mathrm{~g}$. The differences in these results may be due to seeding size and quality of food.
Walne (1972) demonstrated that $R$. decussatus is very sensitive to reductions in temperature from 20 to $10{ }^{\circ} \mathrm{C}$, and lowers its filtration rate by more than $45 \%$. Therefore it appears that the optimum temperature for $R$. decussatus is $c a .20{ }^{\circ} \mathrm{C}$ as its physiological performance is poorer at lower and higher temperatures, due mainly to reduced filtration rates $\left(\mathrm{ca} .45 \%\right.$ reduction at $10{ }^{\circ} \mathrm{C}, 15.9 \%$ at 27 ${ }^{\circ} \mathrm{C}$ and $35.5 \%$ at $32{ }^{\circ} \mathrm{C}$ ). Also Maitre-Allain (1982) showed that Manila clam stop growing at temperatures below $6{ }^{\circ} \mathrm{C}$ and above $19{ }^{\circ} \mathrm{C}$. The main reasons of low growth performance were generally referred to the high temperature (caused physiological stress) and consequently decline feeding rate.

According to Ali (1970), Walne (1972), Winter (1978), Widdows (1978), the increase in temperature over the range $20-32^{\circ} \mathrm{C}$ caused a marked reduction in the scope for growth of $R$. decussatus. Scope for growth declined approximately to zero for temperatures above $27{ }^{\circ} \mathrm{C}$ and was negative at $32{ }^{\circ} \mathrm{C}$. Though partially compensated by an increase in absorption efficiency this reduction was mainly due to the lowering of the energy input (i.e. food consumption) as a result of a decline in feeding rate and this probably reflects the disruption of temperature adaptation mechanisms and inhibition of feeding activity at elevated temperatures as found for species of Crassostrea, Ostrea and Mytilus. Sobral and Widdows (1997) recorded that higher scope for growth or growth performance and survival rate at $20{ }^{\circ} \mathrm{C}$ than 27 and $32^{\circ} \mathrm{C}$. These results agree with Albentosa et a.l. (1994) who determine the optimum thermal condition for growth of clam ( Venerupis pullastra) seed. The optimum temperature was $20{ }^{\circ} \mathrm{C}$ comparable with 10,15 and $25{ }^{\circ} \mathrm{C}$. These results agree with the results in the present study.

The survival rate ranged from $93.75 \%$ at $21{ }^{\circ} \mathrm{C}$ and $100 \%$ at $24{ }^{\circ} \mathrm{C}$. The differences were not significant. The mortality in first trial may be due to low physiological condition or low feeding rate. The survival rate was higher than the previous studies.

\section{REFERENCES:}

Albentosa, M., Beiras, R., \& Camacho, A. P. (1994). Determination of optimal thermal 
conditions for growth of clam (Venerupis pullastra) seed.Aquaculture, 126(3-4), 315328.

Albentosa, M., Pérez-Camacho, A., Labarta, U., \& Fernández-Reiriz, M. J. (1997). Evaluation of freeze-dried microalgal diets for the seed culture of Ruditapes decussatus using physiological and biochemical parameters.Aquaculture, 154(3-4), 305-321.

Albentosa, M., Fernández-Reiriz, M. J., PerezCamacho, A., \& Labarta, U. (1999). Growth performance and biochemical composition of Ruditapes decussatus (L.) spat fed on microalgal and wheatgerm flour diets. Journal of experimental marine biology and ecology, 232(1), 23-37

Ali, R.M. (1970). The influence of suspension density and temperature on the filtration rate of Hiatella arctica. Mar. Biol., 6: 291-302.

Andersen S., Burnell G.G. and Bergh, O.O. (2000). Flow-through systems for culturing great scallop larvae. Aquacult. Int 8:249-257

Anderson, G. J., Miller, M. B. and Chew, K. K. (1982). A guide to Manila clam aquaculture in Puget Sound. Washington Univ. Wash. Sea Grant Prog. Publ.No. WSG, Seattle, WA, pp. 45.

Baud, J. P., and Bacher, C. (1990). Use of saline ground water for intensive rear ing of Ruditapes philippinarum juveniles in a nursery system. Aquaculture 88, 157-178.

Bayne, B.L. \& Newell, R.C. (1983). Physiological energetics of marine molluscs. In: The Mollusca. Vol 4. Physiology, Part I (Saleuddin, A.S.M. \& Wilbur, K.M., eds), pp. 407-515. Academic Press, New York.

Bayne, B.L., Hawkins, A.J.S., Navarro, E. \& Iglesias, J.I.P. (1989). The effects of seston concentration on feeding, digestion and growth in the mussel Mytilus edulis. Mar. Ecol. frog. Ser., 55,47754.

Borowitzka, M.A. (1999). Production of microalgal concentrates for aquaculture (part I: Algae Culture). Final Report to the Fisheries Research and Development (Australia), Project No. 93/123, Canberra, Australia.

Breber, P. (1985). On-growing of the carpet shell clam (Tapes decussatus (L.): Two years' experience in Venice Lagoon. Aquaculture 44, 51-56.

Chessa, G., Serra, S., Saba, S., Manca, S., Chessa, F., Trentadue, M., \& Fois, N. (2013). The floating upwelling system (FLUPSY) for breeding of Venerupis decussata (Linnaeus, 1758) juveniles in a coastal lagoon in Sardinia (Italy). Transitional Waters Bulletin, 7(2), 53-61.
Chool-Shin, H., and Shin, S. H. (1999). Population biology of short necked clam Ruditapes philippinarum: Bivalvia) in Kwangyang Bay, Southern coast of Korea. I. Growth and benthic environments. Korean Journal of Malacology 15, 21-30.

Cigarria, J., Fernández, J. M. (1998). Management of Manila clam beds. I . Influence of seed size, type of substratum and protection on initial mortality. Aquaculture 182, 173-182.

Dhraief, MN., Azaza, MS., Zaafrane, S and Kraïem, MM (2016) Effect of planting size and initial stocking density on growth and survival of cultured carpet shell clam (Ruditapes decussatus L., 1758) in the Akarit estuary (Gulf of Gapes, Tunisia). International Journal of Recent Scientific Research Vol. 7, Issue, 10:13617-13624.

Eversole A., Grimes L., and Eldridge P. (1986). Variability in growth of hard clams, Mercenaria mercenaria. American Malacology. Bulletin 4 (2): 149-155.

Goulletquer, P., Deslous-Paoli, J.M., and Héral, M., (1989). Ecophysiologie et Bilan Energétique de la palourde japonaise d'élevage Ruditapes philippinarum. Jour. Exp. Mar. Biol. Ecol. 132, 85-108.

Goulletquer, P., Robert, R., and Trut, G., (1999). Manila clam Tapes philippinarum culture: Sediment-clam interactions. Aquat. Living Res. 12, 45-56.

Gribben, PE., Creese, R. G., and Hooker, S. H., (2002). Growth rates of the venus clam Ruditapes largillierti grown under experimental culture conditions in New Zealand. Aquaculture 213, 187-197.

Helm MM, and Bourne N. (2004) Hatchery culture of bivalves. A practical manual. In: Lovatelli A (ed) FAO Fisheries Technical Paper 471. Food and Agriculture Organization of the United Nations Publishing, Rome, p 177

Hoffmann, K.H., (1983). Metabolic and enzyme adaptation to temperature and pressure. In: P.W. Hochachka (Editor), The Mollusca, Vol. 2. Academic Press, pp. 220-256.

Jones GG, Sanford CL, and Jones B.L. (1993). Manila Clams: Hatchery and Nursery Methods Innovative Aquaculture Products Ltd., Skerry Bay, Lasqueti Island, B.C., Canada.

Kinne, O. (1971). Temperature. 3.3 Animals. 3.31 Invertebrates. In: 0. Kinne (Editor), Marine Ecology, Vol. 1, Environmental Factors, Part 1. Wiley-Interscience, London, pp. 407-514.

Krom, M.D., Porter, C. and Gordin, H. (1985). Nutrient budget of a marine fish pond in Eilat, Israel. Aquaculture, 5 1: 65-80. 
Laing. I., Utting, S. D., and Kilada, R. W. (1987). Interactive effects of diet and temperature on the growth of juvenile clams. J. Exp. Mar. Biol. Ecol. 113, 2338.

Lake, N. C. H. (1992). Assessment of the potential for Manila clam (Tapes philippinarum) cultivation on the Scottish west coast. Seaf ish report no. 400, Sea fish industry authority, Marine farming unit, Ardtoe, Scotland. pp. 33.

Maitre-Allain, T. (1982). Influence du milieu sur la croissance de deux palurde Ruditupes decussatus et Ruditapes philippimwum, dam 1' etange de Than (Htrault) (Environmental influence on the growth of the clams Ruditapes decussatus and Ruditapes philippinarum in the basin of Than $(\mathrm{H}$ Crault). Vie Mar. 4, 37-49.

Malouf, R.E. and Bricelj, V.M. (1989). Comparative biology of clams: environmental tolerance, feeding, and growth. In: Manzi, J.J., Castagna, M. (Eds.), Clam Mariculture in North America. Elsevier, Amsterdam: pp 2373.

Marshall, R., McKinley, S., and Pearce, C.M. (2010). Effects of nutrition on larval growth and survival in bivalves. Rev. Aquac. 2, 3355.

Matias, D. D. C. C. (2013). Establishment of Environmental and Biological Bases to Optimise the Production of the European Clam Ruditapes decussatus (Linnaeus, 1758), $(\mathrm{PhD})$ Thesis, Univwesidade nova de lisbo (Portugal,).

Motzkin, F., Cohen, Y., Gordin, H., and Padan, E. (1982). Productivity relations in sea water fish ponds: a comparison of stocked and unstacked ponds. Mar. Ecol. Prog. Ser. 8, 203-210.

New MB, Valenti WC (2000) Freshwater prawn culture: the farming of Macrobrachium rosenbergii. Blackwell Science, Oxford, p 52

Otoshi CA, Arce SSM, and Moss SSM (2003). Growth and reproductive performance of broodstock shrimp reared in a biosecure recirculating aquaculture system versus a flow-through pond. Aquacult Eng 29:93-107

Patterson K., Nell J. (1998). Preliminary farming trial of Tapes dorsatus (Lamarck) in four estuaries in New South Wales, Australia. Asian Fisheries Science 11: 149-156.

Pernet, F., Tremblay, R., Demers, E., Roussy, M. (2003). Variation of lipid class and fatty acid composition of Chaetoceros muelleri and Isochrysis sp. grown in a semicontinuous system. Aquaculture 221, 393-406.

Porter, C., Krom, M.D., Robbins, M., Brickell, L. and Davidson, A., (1987). Ammonia excretion and total $\mathrm{N}$ budget for gilthead seabream (Sparus aurata) and its effect on water quality conditions. Aquaculture, 66: 287-297.

Rico-Villa B, Le Coz JR, Mingant C, and Robert $R$ (2006). Influence of phytoplankton diet mixtures on microalgae consumption, larval development and settlement of the Pacific oyster Crassostrea gigas (Thunberg). Aquaculture 256:377-388

Rico-Villa B, Woerther PP, Mingant CC, Lepiver DD, Pouvreau SS, Hamon MM, and Robert RR (2008). A flowthrough rearing system for ecophysiological studies of Pacific oyster Crassostrea gigas larvaee. Aquaculture 282:54-60

Ritar .A.J (2001). The experimental culture of phyllosoma larvaee of southern rock lobster (Jasus edwardsii) in a flow-through system. Aquacult Eng 24:149-156

Robert R., Trut G., and Laborde J. (1993). Growth, reproduction and gross biochemical composition of the Manila clam Ruditapes philippinarum in the Bay of Arcachon, France. Marine Biology 116: 291-299.

Saint-Félix C., Baud J.P. \& Hommebon P. (1984). Diversification de la production conchylicole. Elevage de la palourde japonaise en baie de Bourgneuf. Seience el Pêche, 344 : 2-22.

Sarkis S, Hohn CC, and Helm MM (2006). Larval rearing of calico scallops, Argopecten gibbus, in a flow- through system. Aquacult Int 14:527-538

Serdar, S., Lök, A., Köse, A., Yildiz, H., Acarli, S., \& Goulletquer, P. (2007). Growth and survival rates of carpet shell clam (Tapes decussatus Linnaeus, 1758) using various culture methods in Sufa (Homa) Lagoon, Izmir, Turkey.Aquacultural engineering, 37(2), 89-99.

Shpigel, M., and Fridman, R., (1990). Propagation of the Manila clam (Tapes semidecussatus), in the effluent of fish aquaculture ponds in Eilat, Israel. Aquculture 90, 113-122.

Sobral, P., \& Widdows, J. (1997). Effects of elevated temperatures on the scope for growth and resistance to air exposure of the clam Ruditapes decussatus (L.), from southern Portugal. Scientia Marina, 61, 163171.

Sobral, P., and Widdows, J., (2000). Effects of increasing current velocity, turbidity and particle-size selection on the feeding activity and scope for growth of Ruditapes decussatus from Ria Formosa, southern Portugal. J. exp. Mar. Biol. Ecol. 245, 111-125. 
Spencer, B. E., Edwards, D. B., and Millican, P. F., (1991). Cultivation of Manila clams. Laboratory Leaf let Ministry of Agriculture, Fisheries and Food Directorate of Fisheries Research, No.65, pp.29.

Strickland, J.D.H. and Parsons, T.R., (1972). A Practical Handbook of Seawater Analysis. Fisheries Research Board of Canada, Ottawa, Ont., 310 pp.

Tieman, D.M, and Goodwin, A.A.E. (2001). Treatments for ich infestations in channel catfish evaluated under static and flowthrough water conditions. N Am J Aquacult 63:293-299

Toba, D. R., Tompson, D. S., Chew, K. K., Anderson, G. J., and Miller , M. B., (1992) Guide to manila clam culture in Washington. Seattle, WA, USA, Sea Grant Programme, University of Washington. pp. 80.

Walne, P.R. (1966). Experiments in the largescale culture of the larvae of Ostreu rdulis L. Fish. Invest., Ser. II, Xxv (4): 1-53.

Walne, P.R. (1972). The influence of current speed, body size and water temperature on the filtration rates of five species of bivalves. $J$. mar. biol. Ass. UK, 52: 345-374.

Walne, P. R. (1976). Exper iments on the culture in the sea of the butterfish Venerupis decussata. Aquaculture 8:371-381.

Widdows, J. (1978a). Physiological indices of stress in Mytilus edulis. J. mar. biol. Ass. UK, 58: $125-142$.

Winter, J.E. (1978). A review on the knowledge of suspension-feeding in lamellibranchiate bivalves, with special reference to artificial aquaculture systems. Aquaculture 13: 1-33.

Yamamoto, K., andIwata, F., (1956). Studies on the bivalve, Venerupis japonica, in Akkeshi Lake II. Growth rate and biological minimum size. Bull. Hokkaido Reg. Fish Res. Lab. 14:57-62.

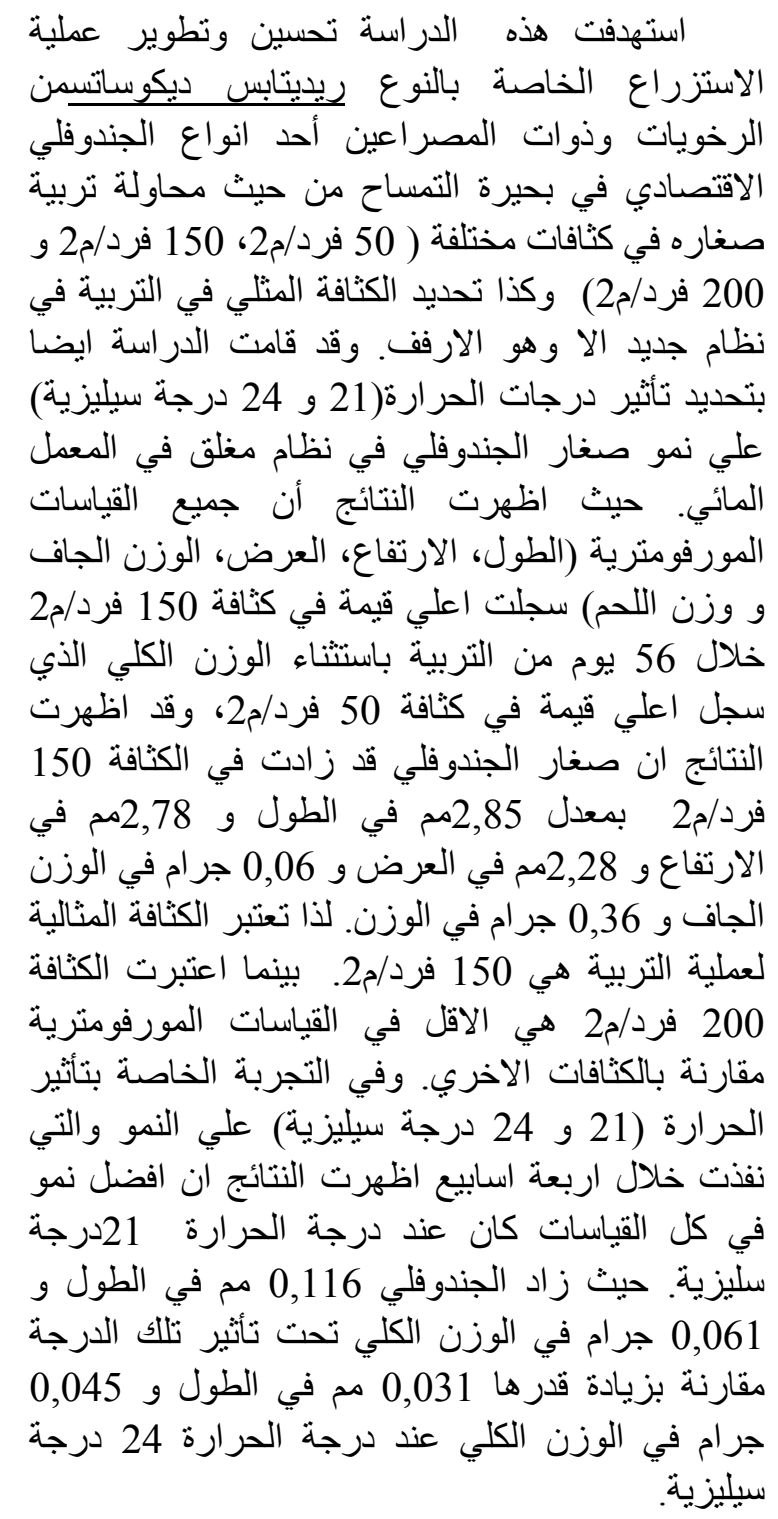

